\title{
Key Factors of China's Economic Emergence
}

\author{
Hanaa Abdelaty Hasan Esmail \\ College of Business Administration, Jazan University, KSA. Theba Academy, Cairo, Egypt \\ Nedra Nouredeen Jomaa Shili \\ College of Business Administration, Jazan University, KSA. PS2D Laboratory, Tunis El Manar
}

Doi:10.5901/mjss.2017.v8n3p251

\begin{abstract}
Our study inquires about the role of China's structural policies in promoting its economic growth by focusing on analysis economic variables affecting on China's economy and the advancement of its sectors. So, we conducted an empirical study that follows the Ordinary Least Square Method (OLS) as an analytical method between determined variable by using multi regression equation. So, we can test the hypotheses of the study, which have a positive effect on the specific economic variables in addition to its impact on GDP during the period. Our sample consists of one country "China" and a period extended from 2000 to 2017. We concluded that the structural policies and the reforms adopted in agriculture, industry, trade and financial sector were favorable to China's economy and made of it an economic power in terms of real economy as proved favorable by the annual growth of its GDP.
\end{abstract}

Keywords: Emergence, Structural Policies, OLS, GFC, Policies, MNEs

\section{Introduction}

There is no doubt that China's economy combines between the developing economy with the transition economy based on industrialization policy and a "newly industrializing country" in the framework of "Socialist Market Economy", which provides the state with an important weight based on the market-driven system.

The combination of rapid growth and large size raises a big question. How did China achieve this economic success?

Some of economists make sure that there is a main reason for the rapid growth in China represented in capital investment funded by local and foreign savings and also productivity growth. Although we believe that the stand occupied par China, in the high hierarchy of word economy is due to a set of coherent and articulate structural policies led in different spheres fields. So, there are so many policy allow China to develop a deep real economic emergence and to become the second power economy in the word. These policies have effectively contributed to China's rapid and economic emergence some factors have had more important role in this process.

As Napoleon Bonaparte once said, "When China awakes, the whole world will shake", a vision that is realized today after about three centuries. Indeed, China is considered today as an important economic power. One of the most remarkable aspects of the changes in the Chinese economy is its international dimension.

In fact, according to the model of planned economy, China worked almost in self-sufficiency until 1979. Since then she knows a great wave of reform under the leadership of Deng Xioping and its famous slogan "Get rich!". Personal enrichment (individualism) and consumption (supported by neo-Keynesian policies in 1997) became new economic engines. Thus, the Chinese economy has grown from a Soviet-style planned economy to "market socialism" with Chinese characteristics, maintaining the rigid structure of control by the Chinese Communist Party.

Before the implementation of economic reforms and trade liberalization more than three decades ago, China kept, through her policies, the economy very unfortunate, inactive, centrally-controlled, vastly ineffective and relatively cut off from the global economy.

Since 1979, China opened up to foreign trade and investment and implemented free markets reforms. Consequently, it became one of the greatest-growing economies with a growth average of nearly $10 \%$ of GDP.

Recently, China became the most important economic power. Its rapid rise as a huge economic power in a short time was a miracle that pulled out around 680 million people from poverty in the period between 1981 and 2012. Based on the purchasing parity power, China is counted as the world's largest economy, manufacturer, merchandise trader, and 
own more reserves of foreign exchange .

According to Angus Maddison (2004), who explained in his study that internal conflicts and foreign wars, coupled with the weakness of the government in addition to distorting economic policies, all these conditions have led to a decline in China's share in the domestic GDP.

China's real distinction is its large size and enormous population. Its quick economic growth makes it a massive importer of consumable goods, technology, and commodities. China's growth became prompt in the 1990s. While the exports reached $\$ 78$ billion in 1993, they increased to $\$ 974$ billion by 2006. By 2007, despite the decline in per capita income, China is still considered the second largest economy in the world in terms of ranking after the United States.

China's economy has seen some recovery and expansion since the end of the Cultural Revolution. Since 1979, the Chinese Government has taken numerous steps to readjust the economy and change the managerial system in order to eliminate the influence of previous mistakes, improve macro economic transactions, and raise standards of living. At the end of 1978, China's government decided to implement a policy of "reform and opening up" (1).

China passed through massive transformation and launched several economic reforms. . it followed many structural reforms which have led to fundamental shifts from oriented economy to a market economy, from an economy based on agriculture to a manufacturing and service-based economy as well as an open economy to the whole world.

\section{Literature Review}

In recent years, some scholars have carried out empirical research on innovation performance in China from the regional and industrial points of view. The major studies from a regional perspective of innovation efficiency in China are summarized as follows.

Regarding to Shi and Zhao, (2009) calculated the regional innovation efficiency in China and analyzed its spatial discrepancy using the stochastic frontier approach. Zhiyun Zhao and Chaofeng Yang (2007) conducted an empirical analysis of the efficiency factors influencing the regional innovation capability differences in China, taking the number of invention patent applications granted as indicators of innovation output. In the same year, Guo et al (2009) analyzed the ability of technology innovation and its influencing factors for the six provinces of central China by establishing a knowledge production function model with fixed effects and variable intercept. Yang (2008) studied the technological innovation capacity of large and medium-sized enterprises in different regions and conducted a comprehensive evaluation using the factor analysis method. The major literature on Chinese innovation efficiency from an industrial perspective is summarized as follow; Zhang \& Feng (2007), through their panel data analysis of 28 sectors in China's high-tech industry, discussed the relationship between market structure, research and development (R\&D) investment and economic performance under different industrial characteristics. Zhi ( 2009) used the stochastic frontier method to analyze the technological innovation performance of China's electronic information industry. Han (2010) also applied the stochastic frontier method to conduct an empirical analysis of the innovation efficiency of China's high-tech industry.

Also Gregory C. Chow and Kui-Wai Li (1993) produced a study to account the economic growth of China with regards to labor, capital and total factor productivity. They presented a Cobb-Douglas production model with reference to official Chinese data. It is an extension of their previous work in 1993 and it has two objectives: to observe whether the production model parameters have changed and to use it to estimate GDP growth up to 2010.

They estimated a Cobb-Douglas production function for the Chinese economy for the period 1952-1998 apart from the years from 1958 to 1969. They examined also the degree of technical improvement in the Chinese economy during the reform years starting with 1978 by introducing a trend variable, which equals zero from 1952 to 1977, equals one in a1978, and increases by one each year thereafter.

The study concluded that there was a clear increase in total factors productivity growth reached to about 0.03 during their periods. Even if that rate falls, it will again rise in the coming decades. This is due to the high expected capital formation rate of more than 30 percent of GDP and the high capital elasticity.

Regarding to Feng Zhen (2008) who discussed the relationship between R\&D expenses and productivity, understood different characters among 39 different industrial sectors by using about 200,000 firm data of 2006 from China National Bureau of Statistics. By using a cross-sectional data with the aim of observing the difference among sectors, he used a simple extended Cobb-Douglas production function. His paper focused on measuring R\&D elasticity among sectors, described the characters and gave a new impression of R\&D impact in China industry by using large data sets and extended Cobb-Douglas production function. Different kinds of capital hold ratios were considered in the function.

\footnotetext{
${ }_{1}^{1}$ State Statistical Bureau of the People's Republic of China and data given in Jingji Nianjian, 1981: Economic Yearbook.
} 
Zhen's conclusions were four. The first is innovation input can improve productivity, especially in market-based, highly competitive sectors. The second is the low level of R\&D elasticity comparing with the results of developed economies. The third is not all high-tech sectors have high elasticity in R\&D, some important high-tech sectors have very low elasticity in R\&D. Finally, the fourth is that different capital ratios influence the productivity significantly in most sectors.

\section{Key Factors of Development in China's Economy}

China's economy has been close to the subsistence border which limits the implementation of economic policy. Agriculture was its main sector but largely unpredictable because of the non-mastery of natural vagaries which is more difficult than that of industrial techniques.

\subsection{Agricultural Sector}

China's economy is based on agriculture. Yet, China is progressively more limited by natural resources, per capita arable land and water resources which are poorer than the world average. The rising demand for main agricultural products have increased and that leads to the improvement of farmers' income, and enhancing the competition between agricultural products.

The structure of Chinese agriculture remains absurd, with a week industrialization level and low value-added agricultural products. The ecological and environmental conditions were poor which entails strict restrictions on the continuous agricultural improvement, joined with thorny food and ecological safety problems.

Economic reforms applied in China's agricultural sector led to a high income growth and China has show up as a major leader of global economic growth. According to the recent statistics, China produces $18 \%$ of the world's cereal grains, $29 \%$ of the world's meat and $50 \%$ of the world's vegetables. This success makes China the world's largest agricultural economy, and it ranks as the largest global producer of pork, wheat, rice, tea, cotton, and fish (2).

Using only $9 \%$ of the global planted area, China produces around $20 \%$ of the world's food which is a miracle since the struggles of 1960s and 1970 faced by the Chinese agricultural sector.

\subsection{Industrial performance of China}

Since the turn of the $21^{\text {st }}$ century, a distinctive Chinese variety of industrial capitalism has taken place. Foreign firms and Chinese efforts for gaining technology lead to the quick industrialization of China which reflects the "stage skipping" phenomenon. As Chinese industrialization jumped directly from imitating mature technologies to innovation, it was described according to some optics as "leapfrogging".

Chinese industrialization raised the country requirements to import aircraft, machinery, production equipment, telecommunications technology, and various raw materials. This situation has advantages as well as inconvenient to international business.

Since the first industrial revolution, the economic change and development could not happen without the improvement of the manufacturing sector. It is associated with higher productivity growth and per capita incomes, described as "structural bonus".

Its accession to the WTO in 2001 helped it to spread out its role as a global manufacturing spot. Thus, China produced massive exports to Europe, the United States, and elsewhere worldwide. Investment has penetrated in China from MNEs which perceive a bright future for the country as a manufacturing platform and huge consumer market.

In 2013 , Chinese manufacturing participated by $35.1 \%$ on the gross value added, this participation was superior to that of the United States. Manufacturing has a central role in China's economy than it has for the United States and Japan. In 2013, China's gross value added manufacturing was equivalent to $28.9 \%$ of GDP, however it reached $12.1 \%$ in the United States and $18.7 \%$ in Japan (3).

\subsection{Employment}

In China, working conditions are far from being ideal, in particular, for the internal migrants. The informal work does not

${ }^{2}$ Carter, C. A. 2011. China's agriculture: achievements and challenges. ARE Update 14:5-7.

3 United Nations, UNdata, available at http://data.un.org 
provide any legal security or social security but, for sure, particularly low and uncertain income. In this regard, China is much better than the countries of the region. It should also be added that the informal labor in China is in many cases the semi-formal work, with some form of security legal and social security (4).

It is difficult to solve the problem of employment in the most populous country in the world. In 2003, 744.32 million people were employed in China, of which 256.39 million in urban areas (34.4\%) and 487930000 in rural areas $(65.6 \%)^{(5)}$. From 1990 to 2003, China has created a total of 96.83 million sets, representing an annual increase of 7.45 million jobs.

In recent years, the Chinese government has taken several steps to control rising unemployment in urban areas where pressure is increasingly heavy on job creation. In late 2003, the registered unemployment rate in urban areas was $4.3 \%$ and there were 8 million registered unemployed. In 2004, the Chinese government has set a goal to create 9 million jobs and 5 million re-employments, keeping the unemployment rate in urban areas around $4.7 \%$.

In the government White Papers, it is mentioned that in the first two decades of the $21^{\text {st }}$ century, China will be building a society with relatively comfortable standard of living. The Chinese government is fully aware that during this period the pressure on employment is still strong, because of the action of the following factors: the originally large number of the population, age structure, migration of the population and the process of social and economic development. During this period, people aged over 16 will increase by 5.5 million annually, and in 2020 there will be a total of 940 million people of working age.

\subsection{Trade}

International trade and investment facilitate the economic growth as they are not only the sources of job creation but also income increase and prices decrease. Countries who are members of the international economy benefit from economic stability and better living standards.

According to trade statistics, recently, China has progressively gained a main role in international trade due to its importance for traditional and largest trading associates such as the United States and the Euro area.

On December 2011, China joined the World Trade Organization, ever since due to its quick trade expansion and profound structural change its economy has continued to grow. After this integration, the Chinese government started to reduce tariffs, extended trade rights and liberalized its regime in order to attract foreign direct investment.

The value of China's merchandise exports increased from \$14 billion in 1979 to $\$ 23$ trillion in 2014 with an annual growth of $18.0 \%$ from 1990 to 2014 , whilst importation of merchandise rose from $\$ 18$ billion to about $\$ 2.0$ trillion with an annual growth of $16.6 \%$ in the same period.

\subsection{Financial Sector}

China's financial system was imbalanced. It was composed only by banks- the big four-with an immature bond and stock markets. Therefore, in order to finance their working capital and investments, all firms depended on bank loans and retained earnings.

However, since 1978 China implemented considerable reforms in order to develop its financial sector. These reforms were basically applied in the banking sector, and manifested as well by the creation of capital markets and development of bonds market as well as opening of the financial system after China's accession to the WTO.

Financial reforms began in the mid-1980s, they changed the shape of Chinese financial system and divided the mono bank People's Bank of China, or PBOC, into a central bank with responsibility to manage monetary policy, and created a system of separately administered state-owned commercial banking entities( ${ }^{(6)}$.

In 1994, the Chinese banking sector witnessed the establishment of the Development Bank, the Export-Import Bank of China, and the Agricultural Development Bank of China, in order to control the lending policies of the Big Four. One year after, the National People's Congress published the Commercial Banking Law, which restricted the Big Four functions to operate only as commercial banks and separated between the business operations of banks, securities firms, and insurance companies.

The banking system has recovered remarkably and it has made progress on the issue of non-tradable shares. Laws have been adopted on the new companies, securities and investment funds, which together constitute a coherent,

\footnotetext{
${ }^{4} \mathrm{http}: / / w w w . u n d p . o r g . b d$

${ }^{5}$ http://www.china.org.cn

${ }^{6}$ World Bank, "China Financial Sector and Institutional Development" (1990).
} 
complete and modern for the development of capital markets. Financial institutions have diversified their activities; housing credit and consumption credit have grown rapidly, and introduced new financial instruments.

During recent years, great steps have been made towards the recovery and modernization of the Chinese banking system. Commercial banks got rid of the huge amount of non-performing loans NPLs that they held at the late 90s. The ratio of these loans to total loans fell from $17.4 \%$ at the end of 2003 to $1.8 \%$ in mid-2009. The sharp decline of nonperforming loans was accompanied by an equally remarkable improvement in banks' capital ratios.

The strategy of modernization and growth followed by China between 1980s and 1990s was the attraction of FDI in order to improve the development of local firms. And by the year 2000, China's leaders encourage Chinese firms to invest overseas. This strategy aims to gain technology, management skills and international brands, needed to help Chinese firms to become more competitive. The stock of China's outward FDI in 2014 is estimated at \$646.3 billion (7).

Since 2005, China has strengthened the legal and institutional foundation of the capital markets and eliminated major barriers to their development. The amended law on companies and securities came into force in 2006 and the Law on Securities Investment Funds in 2004.

The effectiveness of the new texts was improved by the application of the reformed bankruptcy law, which took effect in June 2007, and the amended law on insurance, which took effect in October 2009.

The new laws brought Chinese capital markets close to international practices. They have made a valuable contribution to the reform of non-tradable shares - by the prohibition of trading the state owned shares and corporations accounting for almost two thirds of the capital of listed companies, and which has been long a major obstacle to the development of stock markets - and restructuring the Professional Title, as well as new product development and international integration of Chinese capital markets ${ }^{(8)}$.

The Global Financial Crisis (GFC) has accelerated the reorganization and partial fragmentation of global financial order. In recent years, Emerging countries became a major force in the global economy. In particular, China's economy has made leaps in its potential and actual financial power while others are lagging behind.

\section{Methodology}

This paper draws an illustration of the factors which drive China's economic emergence. Thus, we analyzed China's emergence by studying the impact of growth on some sectors in china's economy on growth domestic product as an indicator to economic development in China. So we will use the Ordinary Least Square Method (OLS) as an analytical method between determined variable by using multi regression equation.

\subsection{Hypothesis}

We believe that the stand occupied par China, in the high hierarchy of the world economy is due to a set of coherent and articulate structural policies led in different spheres fields. Our research hypotheses are the following:

- Agriculture might have favorable impact on Chinese GDP as it is the foundation of China's national economy and has been renovated.

- Industrial structural policies will take time to impact positively China's GDP as its result will be seen on the long run.

- After its accession to the WTO, Trade effect on China's GDP is favorable.

- The foreign direct investments FDI have a positive and significant impact on China's economic growth.

\subsection{Nature}

This paper is an analytical in nature. It uses both inferential and descriptive by analyzing all hypothesis assumed in this paper to carry out the objectives of the study.

\subsection{Time series}

The period of the study extended from 2000 to 2017 including financial crises period.

\footnotetext{
7 United Nations conference on Trade and development

${ }^{8}$ Chinese Commission for securities regulation, 2008.
} 


\subsection{Used Techniques}

The study applied Ordinary Least Squares (OLS) to run multiple regressions on time series variables using SPSS or Eviews Program by depending on Durbin Watson (D-W) test and correlation matrix between all variable.

$Y:$ :GDP: growth (annual \%)

X1 : AGR: approximated China's Agricultural value added (\%GDP)

$\mathrm{X} 2$ : IND: approximated by China's Industry value added (\%GDP)

$\mathrm{X} 3$ : Exports (\%GDP)

$\mathrm{X} 4$ : Imports (\%GDP)

$\mathrm{X} 5$ : FDI (\%GDP)

$\mathrm{X} 6$ : Unemployment rate $\%$

\section{Result}

The results of an analytical study by using SPSS Program to analyze China's various economic variables and their impact's on the GDP growth rate were shown in the multi regression model are significant and explained $96 \%$ at a significant level 0.000 . Also the value of Durbin Watson equal 1.895 and independent variables in the model are interpreted as ratio $92 \%$.

According to correlation matrix in table No (4) there is significance of correlation coefficients between most variables, so we can highlights Equation regression as follows:

$Y=-16.228+0.107 X_{1}+0.211 X_{2}+0.049 X_{3}+0.014 X_{4}+0.839 X_{5}+2.451 X_{6}$

According to these results we can conclude that, Agriculture has a favorable impact on Chinese GDP as it is the foundation of China's national economy and employs a large number of workforces. Therefore it reduces the city crowd. This is due to its position as the first agricultural producer of many products. China has an important share in the world agricultural production and this is a result of the efficiency of its agricultural reforms. China is one of the large producers of many agricultural products such as rice, tea, cotton...

Industry has a favorable and significant contribution in the Chinese production emergence. The Chinese industrial sector, with a gigantic and diversified industrial area, contributes in giving more importance to the Chinese position in international economic hierarchy. The percentage of Chinese manufactured production, compared to the international manufactured industry, is one of the highest in the world.

In order to emerge, industrial reforms in China as which aimed to strengthen the industrial fabric of the nation against foreign competitors, made of it an increasing economic power.

Trade effect on GDP expressed in our model by export and imports is favorable. This can be explained by the fact that China is the first trade power especially after its accession to the WTO which created enormous business opportunities and consequently we can conclude that imports and exports have a positive and significant contribution in China's economic emergence.

Moreover we notice that the foreign direct investments FDI have a favorable and important impact on China's economic growth. This result comforts those loyal to the openness to foreign capitals. These investments create jobs and a significant value added. As China is the leading country in FDI share due to the very low labor cost with a docile and qualified workforce, the role of FDI in growth remains capital.

As FDI is concentrated in industrial sector, it has resulted in a positive and significant effect of the variable industry on China's growth. This sector absorbs significant part of qualified and non-qualified workforce. Its contribution to the economic emergence of China is clear. This explains the positive contribution of Chinese employment rate on its GDP.

Since last ten years, the labor market, witnessed a period of profound change. In companies, the increase of nonState controlled activities strengthened the role of the private sector. Implementing a labor law was a difficult task in China, even when the parts are equal.

A new labor regulation was therefore established in 2008 in order to implement a more equitable basis for cooperation between employers and employees in a market dominated by private sector employers.

\section{Conclusion}

In conclusion, it is confirmed that structural policies and reforms adopted in agriculture, industry, trade and finance were favorable to China's economy and made of it an economic power in terms of real economy as proved favorable by the annual growth of its GDP. 
As a world economic power, and in an interdependent world, the emergence of China is certainly one of the striking phenomena of the world economy which China upsets both regional and global hierarchies and should lead to increased trade and create jobs and wealth.

Due to its economic development in the agricultural sector, industrial and commercial, supported by the size of its population and the strength of its civilization, China emerges smoothly to become one of the economic superpowers of the twenty-first century.

After winning in 2013 the title of the world's leading trading power ahead of the United States, China managed its policies to become the first economy in the world earlier than expected (2014 against 2019). This is due to the fact that China passed through massive transformation and launched several economic reforms such as China's Five-Year Plans, the National Program for S\&T development and Third Plenum Economic Policies.

\section{Recommendation}

Emergence has a variable nature making it difficult for an analytical concept. As well as by reference to its determinants, international organizations rank in the emerging category highly developed countries as well as least developed countries.

In our study, we could have induced the social factor in the determinants of economic emergence.

The study of Chinese experience remains incomplete outside a historical and geopolitical analysis of China; a study of international economic relations could deepen our research.

\section{References}

Branstetter , Lee, and Nicholas R. Lardy (2008) , "China's Embrace of Globalization." In China's Great Economic Transformation, edited by Loren Brandt and Thomas G. Rawski . Cambridge University Press. www.heinz.cmu.edu/

Carter, C. A. (2011), "China's agriculture: achievements and challenges". ARE Update 14:5-7.http:// www.qualityassurancemag.com/

Chinese Commission for securities regulation, 2008.

Chung-ping. Y. et al(1955), "Selected Statistical Material on the Modern Economic History of China". Peking. http://wrap.warwick.ac.uk/57944/

Colin A. Carter(2011), "China's Agriculture: Achievements and Challenges". Agriculture and Resource Economics Update, Vol. 14, No. 5, May/June https://giannini.ucop.edu.

Douglas. J. Elliott and Kai Yuan,(2013), "The Chinese Financial System: An Introduction and Overview". Jhon L. Thornton China Center Monograph Series. №6. https://www.brookings.edu/

http://www.undp.org.bd

Kynge. J. (2009)., "China shakes the world: the rise of a hungry nation." London: Phoenix https://www.abebooks.com/

Zhiyun Zhao and Chaofeng ( 2007), "An Empirical Study of China's High-Tech Industry Innovation Capability in Transition", http://pressfiles.anu.edu.au/downloads

Li, X., Liu, X. and Parker, D (2011), "Foreign Direct Investment and Productivity Spillovers in the Chinese Manufacturing Sector". Economic Systems, 25: 305-321. www.academia.edu

Lin Wei, Arnold Chao(1983), China's Economic Reforms". University of Pennsylvania Press. https://www.cambridge.org/

State Statistical Bureau of the People's Republic of China and data given in Jingji Nianjian, (1981) Economic Yearbook.

Szirmai. A., (2012), "Industrialization as an engine of Growth in developing countries, 1950-2005". Structural Change and Economic Dynamics, 23 (4), December. https://ideas.repec.org/

The Organization for Economic Cooperation and Development (2007), Chinese Economic Performance in the Long Run, 960-2030, by Angus Maddison, . https://www.amazon.com/Chinese-Economic-Performance/

Timmer, M. and Szirmai, A. (2000), "Productivity Growth in Asian Manufacturing: The structural Bonus Hypothesis Examined", Structural Change and Economic Dynamics, 11:371-392. www.sciencedirect.com

United Nations conference on Trade and development

United Nations, UNdata, available at http://data.un.org

Whalley. J. and Hamilton. C. (1996), "The Trading System after the Uruguay Round". Washington DC: Institute for International Economics. http:// www.economics.uwo.ca/research/

World Bank (2017), "China Financial Sector and Institutional Development. http://www.worlddatabank.org

Xinhua News Agency, Highlights of China's $12^{\text {th }}$ Five-Year Plan, March 5, 2011; and APCO Worldwide, China's $12^{\text {th }}$ Five-Year Plan: How it Actually Works and What's in store For the Next Five Years, December 10, 2010. https://www.uscc.gov/sites/default/

Xu,Chenggang.(2011), "The Fundamental Institutions of China's Reforms and Development." Journal of Economics Literature 49 (4): 1076-1151. https://www.aeaweb.org/articles. 


\section{Appendix}

Table 1: Economic variables of China

\begin{tabular}{|c|c|c|c|c|c|c|c|}
\hline Year & GDP & AGR & IND & EX & Imp & FDI & Unemployment \% \\
\hline 2000 & 8.5 & 14.7 & 45.5 & 21.2 & 18.5 & 3.49 & \\
\hline 2001 & 8.3 & 14 & 44.8 & 20.8 & 18.2 & 3.53 & \\
\hline 2002 & 9.1 & 13.3 & 44.5 & 23 & 20.1 & 3.63 & 4 \\
\hline 2003 & 10 & 12.3 & 45.9 & 27.8 & 24.8 & 3.51 & 4.3 \\
\hline 2004 & 10.1 & 12.9 & 47 & 31.8 & 28.4 & 3.51 & 4.2 \\
\hline 2005 & 11.4 & 11.6 & 47.6 & 34.5 & 28.4 & 4.59 & 4.2 \\
\hline 2006 & 12.7 & 10.6 & 46.9 & 37.2 & 28.4 & 4.88 & 4.2 \\
\hline 2007 & 14.2 & 10.3 & 45.9 & 35.9 & 26.7 & 4.44 & 4.1 \\
\hline 2008 & 9.7 & 10.3 & 46.4 & 32 & 24.9 & 3.76 & 4 \\
\hline 2009 & 9.4 & 9.8 & 46.4 & 24.4 & 20.1 & 2.59 & 4.2 \\
\hline 2010 & 10.6 & 9.5 & 46.4 & 26.3 & 22.6 & 4.04 & 4.3 \\
\hline 2011 & 9.5 & 9.4 & 46.4 & 26.5 & 24.1 & 3.74 & 4.1 \\
\hline 2012 & 7.9 & 9.4 & 45.3 & 25.4 & 22.7 & 2.85 & 4.1 \\
\hline 2013 & 7.8 & 9.3 & 44 & 24.5 & 22.1 & 3.07 & 4.1 \\
\hline 2014 & 7.3 & 9.1 & 43.1 & 24.1 & 21.6 & 2.59 & 4.1 \\
\hline 2015 & 6.9 & 8.9 & 40.9 & 22.1 & 18.6 & 2.3 & 4.05 \\
\hline
\end{tabular}

Source : World Data Bank Report, 2017

Table 2: Model Summary

\begin{tabular}{|c|c|c|c|c|c|c|c|}
\hline Model & $\mathrm{R}$ & R Square & Adjusted R Square & Std. Error of the Estimate & Durbin-Watson & $\mathrm{F}$ & Sig. \\
\hline 1 & $.980^{\mathrm{a}}$ & .961 & .928 & .5090 & 1.895 & 28.789 & $.000^{\mathrm{a}}$ \\
\hline
\end{tabular}

Table 3: coefficients

\begin{tabular}{|l|c|c|c|c|c|}
\hline \multirow{2}{*}{ Model } & \multicolumn{2}{|c|}{ Un standardized Coefficients } & Standardized Coefficients & \multirow{2}{*}{ T } & Sig. \\
\cline { 2 - 4 } & $\mathrm{B}$ & Std. Error & Beta & -2.431 & .045 \\
(Constant) & -16.228 & 6.676 & & .995 & .353 \\
Agric. V. added & .107 & .108 & .083 & 1.584 & .157 \\
Industrial. V. added & .211 & .133 & .202 & .857 & .420 \\
Exports & .049 & .057 & .131 & 5.448 & .001 \\
Imports & .014 & .003 & .498 & 2.370 & .050 \\
FDI & .839 & .354 & .350 & 1.435 & .194 \\
Unemployment & 2.451 & 1.708 & .125 & & \\
\hline
\end{tabular}

Table 4: Correlation Matrix

\begin{tabular}{|c|c|c|c|c|c|c|c|}
\hline & GDP & Agri. & Indus. & Exports & Imports & $\mathrm{FDI}$ & Unemployment \\
\hline \multirow{2}{*}{ GDP } & 1 & .087 & $.679^{*+*}$ & $.839^{*+*}$ & $.700^{*+*}$ & $.829^{*+*}$ & .312 \\
\hline & & .749 & .004 & .000 & .003 & .000 & 277 \\
\hline \multirow[b]{2}{*}{ Agri } & .087 & 1 & .247 & -.136 & -.098 & .264 & .153 \\
\hline & .749 & & .356 & .616 & .719 & .323 & .601 \\
\hline \multirow{2}{*}{ Indus } & $.679^{+*}$ & .247 & 1 & $.627^{* *}$ & .111 & $.704^{* t *}$ & .487 \\
\hline & .004 & .356 & & .009 & .683 & .002 & .078 \\
\hline \multirow{2}{*}{ Exports } & $.839^{+1 *}$ & -.136 & $.627^{\text {th }}$ & 1 & .477 & $.745^{\text {t* }}$ & .232 \\
\hline & .000 & .616 & .009 & & .062 & .001 & .425 \\
\hline \multirow{2}{*}{ Imports } & $.700^{* *+}$ & -.098 & .111 & .477 & 1 & .363 & -.098 \\
\hline & .003 & .719 & .683 & .062 & & .167 & .740 \\
\hline \multirow{2}{*}{ FDI } & $.829^{+1+}$ & .264 & $.704^{* t+}$ & $.745^{* *}$ & .363 & 1 & .270 \\
\hline & .000 & .323 & .002 & .001 & .167 & & .350 \\
\hline \multirow{2}{*}{ Unemployment } & .312 & .153 & .487 & .232 & $\begin{array}{l}.098 \\
\end{array}$ & .270 & 1 \\
\hline & .277 & 601 & .078 & .425 & .740 & .350 & \\
\hline
\end{tabular}

